\title{
Pengaruh Model Pembelajaran Learning By Doing Terhadap Kemampuan Penalaran Siswa Di SMKS-PP Putra Jaya Jabal Rahmah Stabat
}

Khairunnisa ${ }^{1}$, Isnaida ${ }^{2}$, Ispandi Manurung ${ }^{3}$

1,2,3 STAI Jam'iyah Mahmudiyah Tanjung Pura, Langkat

ABSTRACT
This study aims to determine the effect of the Learning By Doing model on
the reasoning abilities of students in class X SMKS-PP Putra Jaya Jabal
Rahmah Stabat, Langkat Regency. This research is a type of quasi-
experimental research (quasi-experimental) with a nonequivalent control
group design. The population in this study were all students of class X
SMKS-PP Putra Jaya Jabal Rahmah with the determination of the sample
through random sampling technique (random sampling). Based on this
technique, obtained class X Livestock B as the experimental class and class X
Plantation B as the control class. Each class consists of 34 and 35 students.
Data collection techniques using test techniques, namely pretest and posttest.
The validation used is Pearson correlation which shows the instrument is
valid. Reliability test using Alpha Crobanch which shows a reliability index
of 0.665 for the pretest instrument and 0.66 for the posttest instrument, which
means both are reliable. Before analyzing the data, the normality test and
homogeneity test were conducted which showed that the pretest and posttest
scores were normally distributed and homogeneous. The data analysis
technique used is linear regression test (F test) by comparing the Fcount
value of 24.47 and F table of 7.56 , then the Fcount> Ftable value is $24.47>7.56$.
Thus, the results of the study indicate that there is a significant influence
from the application of the learning by doing learning model on the
reasoning abilities of Class X students of SMKS-PP Putra Jaya Jabal Rahmah
in the subjects of Islamic religious education and character.

Keywords

Learning by Doing Model, Student Reasoning Ability.

\section{PENDAHULUAN}

Belajar menjadi suatu kegiatan penting bagi kehidupan manusia. Setiap proses yang dilalui dalam kehidupan akan memberikan pengalaman yang berarti bagi manusia, sehingga pengalaman tersebut dapat dijadikan pembelajaran bagi diri sendiri. Belajar dapat dilakukan kapan pun dan di mana pun, secara informal maupun formal. Salah satu tujuan utama dari belajar adalah mendapatkan ilmu pengetahuan dan adanya perubahan tingkah laku setelah mendapatkan pembelajaran. Pembelajaran yang kita lakukan tentunya membutuhkan bantuan dari pihak lain, terutama orang tua dalam lingkungan tempat tinggal dan guru dalam lingkungan formal, serta pihak-pihak tertentu lainnya yang berada di lingkungan sekitar. Pembelajaran menurut Uno (2011: 47) merupakan perpaduan antara kebutuhan belajar dan aktivitas mengajar yang harus berjalan sesuai harapan. Harapan tersebut adalah segala sesuatu 
yang menjadi kebutuhan siswa yang belajar sebagai pelajar, sehingga terarah tujuan pembelajaran yang telah dirumuskan oleh guru.

Setiap manusia memerlukan pendidikan dari kecil hingga dewasa, dimulai sejak dini hingga perguruan tinggi. Pendidikan formal menjadi prioritas utama bagi orang tua yang menginginkan anaknya menjadi insan yang lebih baik serta memperoleh berbagai ilmu pengetahuan yang nantinya dapat berguna bagi kehidupan di masa depan. Maka, guru memiliki peran penting dalam hal mencerdaskan anak bangsa, namun tidak terlepas dari dukungan orang tua sebagai guru utama dalam lingkungan tempat tinggal (rumah). Oleh karena itu, seorang guru memerlukan berbagai cara untuk memberikan pendidikan yang terbaik bagi peserta didiknya. Salah satu hal yang dapat dilakukan guru adalah menerapkan berbagai model pembelajaran yang dapat menambah wawasan dan berbagai kemampuan yang harus dimiliki peserta didik setelah mendapatkan pembelajaran.

Salah satu model pembelajaran tersebut adalah model pembelajaran learning by doing. Istilah learning by doing dalam bahasa Indonesia diartikan sebagai pembelajaran dengan melakukan sesuatu. Menurut Nur dalam Kusmanto (2014: 67) menyatakan bahwa pembelajaran melalui learning by doing dilakukan dengan merancang kegiatan sederhana yang dapat menggambarkan konsep yang sedang dipelajari, di mana dalam pembelajaran tersebut siswa tidak hanya mengetahui konsep pembelajaran secara teoritis, tetapi juga secara praktis. Sebagaimana aliran konstruktivisme menyatakan bahwa pembelajaran akan berlangsung secara efektif apabila siswa terlibat langsung dalam tugastugas autentik yang berhubungan dengan konteks secara lebih bermakna. Dari penerapan model pembelajaran learning by doing tersebut, tentu diharapkan tercapainya tujuan dalam pembelajaran. Salah satunya kemampuan yang harus dimiliki oleh peserta didik setelah mendapatkan pembelajaran melalui model pembelajaran tersebut yaitu kemampuan penalaran.

Kemampuan penalaran merupakan salah satu kemampuan yang menuntut peserta didik untuk berfikir secara logis dan dapat mengutarakan atau mengungkapkan alasan maupun pendapat atas suatu permasalahan yang diberikan. Namun, pada kenyataannya dalam kegiatan belajar mengajar, khususnya tingkat sekolah menengah kejuruan (SMK) peserta didik masih memiliki ketergantungan kepada guru untuk dapat membantu mereka menjelaskan atau mengutarakan kalimat yang ada dalam fikiran mereka. Salah satu kendala yang dihadapi peserta didik tersebut adalah kurangnya rasa percaya diri dengan kemampuan yang dimilikinya, bahkan takut salah dan takut tidak sesuai dengan jawaban yang diharapkan oleh guru. Padahal apapun jawaban yang diberikan peserta didik, pada akhirnya akan dijelaskan kembali 
oleh guru jika terdapat ketidaksesuaian atau kekeliruan dalam jawaban peserta didik. Oleh karena itu, dalam penelitian ini penulis mengharapkan peserta didik memiliki kemampuan penalaran yang baik setelah diberikan materi pelajaran yang disesuaikan dengan model pembelajaran yang dapat meningkatkan kemampuan peserta didik, terutama kemampuan penalaran.

\section{Model Pembelajaran Learning by Doing}

Model pembelajaran menjadi salah satu landasan atau dasar kegiatan pembelajaran yang dilakukan oleh guru kepada siswa. Guru perlu memilih dan menerapkan model pembelajaran yang sesuai dengan tujuan pembelajaran dari materi yang diajarkan. Menurut Istarani (2014: 1) model pembelajaran merupakan rangkaian kegiatan penyajian materi ajar yang meliputi segala aspek sebelum, sedang dan sesudah pembelajaran dilakukan oleh guru serta segala fasilitas terkait yang digunakan secara langsung atau tidak langsung dalam proses belajar mengajar. Sedangkan Uno (2007: 32) menyatakan bahwa model pembelajaran membantu siswa menemukan makna diri (jati diri) di dalam lingkungan sosial dan memecahkan dilema dengan bantuan kelompok. Hal ini berarti bahwa penggunaan model dalam pembelajaran memberikan kesempatan kepada siswa untuk mengeksplor segala bentuk kemampuan yang mereka miliki dalam suatu bentuk kerjasama yang dilakukan dalam sebuah kelompok belajar, dalam kelompok tersebut siswa juga dapat belajar untuk dapat menerima dan saling membantu menyelesaikan permasalahan secara bersama-sama.

Pada saat ini, model pembelajaran yang umumnya dan harus diterapkan adalah model pembelajaran yang berpusat kepada siswa, berbasis masalah dan dilakukan secara berkelompok. Sehingga, secara tidak langsung siswa harus dapat mengemukakan atau mengutarakan ide-idenya atas seuatu permasalahan yang diberikan diawal pembelajaran serta dapat menerima segala bentuk kekurangan yang dimiliki oleh setiap teman yang menjadi anggota dalam kelompoknya. Berbagai macam model pembelajaran yang dapat diterapkan oleh guru, hal itu dilakukan untuk menarik rasa ingin tahu, perhatian, dan minat siswa dalam mempelajari materi pelajaran yang diberikan. Sehingga, siswa tidak merasa jenuh dan selalu merasakan suasana baru dalam melaksanakan pembelajaran. Salah satu model pembelajaran tersebut adalah model pembelajaran learning by doing.

Model pembelajaran learning by doing adalah suatu aktivitas belajar yang melibatkan baik itu fisik maupun mental. Selain itu tidak hanya sebatas mengembangkan aspek kognitif tetapi juga dampaknya terhadap aspek afektif. Hal ini terjadi karena ketika siswa belajar terjalin hubungan antara dirinya 
dengan subyek yang dia pelajari. Sehingga, akan ada hal-hal atau pengalaman baru yang harus siswa temukan sendiri.

Model pembelajaran learning by doing ini berlndaskan bahwa pembelajaran haruslah memberikan makna bagi siswa dalam hidupnya. Sasaran dari kegiatan pendidikan adalah untuk mempersiapkan siswa agar mampu menggenggam makna untuk apa dia belajar dan paham apa yang dia pelajari. Jika tidak demikian, maka belajar tidak lain hanyalah sesuatu yang hampa, sebuah usaha mengumpulkan data-data, suatu kegiatan yang tidak ada aplikasinya dalam kehidupan di luar sekolah. Karena, model pembelajaran learning by doing menjadi salah satu model pembelajaran yang berpusat pada siswa dan sebagai sebuah usaha agar para siswa dapat mengerti dan memahami secara lebih baik terhadap apa yang telah mereka peroleh dalam belajar. Sehingga, pada akhirnya hasil belajar nantinya menjadi watak bagi dirinya untuk menentukan sikap dalam kehidupan masa depan yang akan dijalaninya.

\section{Kemampuan Penalaran Siswa}

Terdapat berbagai kemampuan yang harus dimiliki seorang siswa setelah mendapatkan pembelajaran oleh guru di sekolah. Karena, pada hakikatnya segala bentuk pembelajaran yang diberikan oleh guru memiliki tujuan terhadap peserta didik. Hal tersebut dapat dilihat dari berbagai aspek tujuan pembelajaran yaitu kognitif, afektif dan psikomotorik. Namun, dalam penelitian ini yang menjadi titik fokus adalah kempuan penalaran siswa melalui model pembelajaran learning by doing.

Istilah penalaran merupakan terjemahan dari reasoning. Menurut Shurter dan Pierce dalam Arcat dan Lusi (2017: 36) mendefinisikan penalaran sebagai proses pencapaian kesimpulan logis berdasarkan fakta dan sumber yang relevan. Begitu pun menurut Suherman dan Winataputra dalam Arcat dan Lusi (2017: 26) yang menyatakan bahwa penalaran adalah proses berpikir yang dilakukan dengan cara menarik kesimpulan. Kesimpulan yang bersifat umum dapat ditarik dari kasus-kasus yang bersifat individual, tetapi dapat pula sebaliknya, dari hal yang bersifat umum menjadi khusus yang bersifat individual.

Lebih lanjut Suriasumantri dalam Arcat dan Lusi (2017: 36) mengemukakan ciri-ciri dari penalaran yaitu 1) adanya suatu pola berpikir yang secara luas dapat disebut logika. Hal ini berarti di dalam penalaran memiliki logika tersendiri. Oleh karena itu penalaran biasa disebut dengan proses berpikir logis, yang berarti kegiatan berpikir menurut pola atau logika tertentu; 2) penalaran dilihat dari proses berpikirnya bersifat analitik, yang merupakan suatu konsekuensi dari adanya suatu pola berpikir tertentu. Jadi 
analitik adalah suatu kegiatan berpikir berdasarkan langkah-langkah tertentu. Hal lain terkait penalaran juga diungkapkan oleh Sastrosudirjo dalam Alamsyah (2000: 28) yang menyatakan bahwa kemampuan penalaran meliputi: 1) penalaran umum yang berhubungan dengan kemampuan untuk menemukan penyelesaian atau pemecahan masalah, 2) kemampuan berdeduksi, yaitu kemampuan yang berhubungan dengan penarikan kesimpulan, seperti pada silogisme, dan yang berhubungan dengan kemampuan menilai implikasi dari suatu argumentasi, dan 3) kemampuan untuk melihat hubunganhubungan, tidak hanya hubungan antara benda-benda tetapi juga hubungan antara ide-ide, dan kemudian mempergunakan hubungan itu untuk memperoleh benda-benda atau ide-ide lain.

Dengan demikian, kemampuan penalaran siswa menjadi salah satu kemampuan yang diharapkan dimiliki oleh siswa sesaat dan setelah diterapkannya model pembelajaran learning by doing. Kemampuan penalaran merupakan kemampuan terkait cara berfikir siswa terhadap suatu persoalan atau permasalahan yang diberikan. Bagaimana siswa tersebut dapat mengutarakan atau mengemukakan pendapat serta alasan terhadap sesuatu. Bahkan, jika perlu siswa tersebut memberikan bukti (proof) terhadap pendapat atau alasan yang diberikan. Kemampuan penalaran siswa tentu berbeda antara siswa yang satu dengan lainnya, bahkan antara siswa yang duduk di bangku sekolah dasar dengan siswa yang duduk di bangku sekolah menengah pertama, menengah atas hingga perguruan tinggi. Sedangkan dalam hal ini yang menjadi fokus penelitian adalah kemampuan penalaran siswa kelas $X$ SMKS-PP Puta Jaya Jabal Rahmah Kelurahan Perdamaian, Kecamatan Stabat, Kabupaten Langkat

Permasalahan lain yang terdapat pada siswa SMK ini adalah mereka terbiasa melaksanakan pembelajaran di luar ruangan dan teah terbiasa melaksanakan praktikum di ruangan terbuka atau ruangan lain yang mendukung kejuruan mereka. Sehingga pembelajaran di luar kejuruan terkesan monoton, maka siswa pun merasa jenuh dan kurang berminat untuk mengikuti pelajaran tersebut. Apalagi mata pelajaran seperti pendidikan agama Islam yang memiliki jam pelajaran yang sedikit, yaitu hanya dua jam mata pelajaran perminggunya. Maka dari itu model pembelajaran learning by doing dirasa tepat untuk mengatasi problema tersebut, yang langsung dapat di praktikkan oleh guru dalam pembelajaran pendidikan Agama Islam dan budi pekerti.

Guru perlu memilih dan menentukan model pembelajaran yang tepat untuk digunakan agar dapat mempengaruhi berbagai kemampuan yang dimiliki peserta didik, terkhusus kemampuan penalaran siswa, jika siswa dapat terfokus dalam suatu permasalahan belajar dan berkonsentrasi penuh maka 
penalaran yang dimiliki oleh siswa akan bekerja dengan maksimal dan materi pelajaran dapat diserap atau ditangkap oleh siswa dengan baik pula. Penalaran masing-masing siswa berbeda, namun apabila siswa dapat terus memusatkan perhatiannya pada materi pelajaran, maka sekaligus ia mengasah kemampuan penalarannya. Oleh sebab itu, seorang guru harus mampu menggunakan secara optimal suatu pendekatan, model, metode, atau design dalam pembelajaran.

Jika model pembelajaran yang digunakan oleh guru kurang menarik dan tidak sesuai dengan materi pelajaran yang diberikan, maka bisa saja mempengaruhi semangat atau keinginan belajar siswa dalam mengikuti pelajaran di dalam kelas, sehingga dapat berakibat rendahnya penalaran siswa. Oleh karena itu, seorang guru harus dapat menggunakan model pembelajaran yang menarik dan sesuai dengan kebutuhan siswanya. Sehingga, diharapkan melalui penerapan model pembelajaran learning by doing ini dapat memberikan perubahan/pengaruh atau bahkan peningkatan terhadap kemampuan penalaran siswa dalam mata pelajaran pendidikan agama Islam dan budi pekerti bagi siswa kelas X SMKS-PP Putra Jaya Jabbal Rahmah Stabat Tahun Ajaran 2016/2017.

\section{METODE PENELITIAN}

Jenis penelitian yang digunakan adalah penelitian dengan menggunakan pendekatan kuantitatif. Penelitian ini dikategorikan ke dalam penelitian eksperimen semu (quaci experiment) karena kelas yang dijadikan sampel adalah kelas yang telah terbentuk sebelumnya. penelitian ini juga menggunakan dua kelompok subjek penelitian yaitu kelompok eksperimen dan kelompok kontrol. Pendekatan kuantitatif digunakan untuk memperoleh gambaran tentang kemampuan penalaran siswa setelah diterapkannya model pembelajaran learning by doing.

Populasi dalam penelitian ini meliputi seluruh siswa kelas X SMKS-PP Putra Jaya Jabal Rahmah. Terpilihnya siswa kelas X sebagai populasi penelitian dikarenakan siswa kelas $\mathrm{X}$ sudah masuk pada kategori mencapai masa perkembangan emosional yang baik sehingga mampu mengarahkan diri pada perbuatan yang positif.

Penelitian ini dikategorikan kedalam penelitian eksperimen semu (quasi experiment). Desain yang digunakan dalam penelitian ini meliputi tiga tahapan, yaitu : (1) Tahap penyusunan perangkat pembelajaran, dan instrument penelitian. (2) tahap uji coba perangkat pembelajaran dan instrument penelitian. (3) tahap pelaksanaan penelitian. Setiap tahapan dirancang sedemikian rupa sehingga dapat diperoleh data yang valid dalam penelitian yang dilakukan sesuai dengan karakteristik variabel dan juga sesuai dengan 
tujuan penelitian. Setelah melakukan pengembangan perangkat dan uji coba perangkat, penelitian ini dilanjutkan pada pelaksanaan eksperimen. Rancangan eksperimen ini menggunakan rancangan eksperimen pretes-postes dua kelompok yaitu kelompok eksperimen dan kelompok kontrol. Intrumen yang digunakan dalam penelitian ini terdiri dari dua jenis instrument, yaitu jenis tes dan non tes. Instrument jenis tes berupa soal berbentuk uraian yang digunakan sebagai instrument untuk mengukur kemampuan penalaran siswa sedangkan instrument jenis non tes berupa angket terhadap respon siswa selama pembelajaran berlangsung, dan lembar observasi terkait kemampuan pendidik dalam mengelola pembelajaran. Teknik analisis data yang digunakan dalam penelitian ini adalah analisis data secara inferensial. Data yang dianalisis secara inferensial adalah data berupa hasil pretes dan postes kemampuan penalaran siswa.

\section{HASIL DAN PEMBAHASAN}

Hasil penelitian yang akan dibahas terkait dengan pengaruh model pembelajaran learning by doing sebagai variabel bebas terhadap kemampuan penalaran siswa sebagai variabel terikat. Dalam penelitian ini diharapkan model pembelajaran learning by doing pada mata pelajaran pendidikan agama Islam dan budi pekerti di kelas X SMKS-PP Putra Jaya Jabal Rahmah berpengaruh secara signifikan terhadap kemampuan penalaran siswa. Berdasarkan kedua variabel tersebut, maka peneliti akan membahas hasil penelitian yang telah diperoleh sebagai berikut.

\section{Penerapan Model Pembelajaran Learning by Doing}

Model pembelajaran learning by doing yang diterapkan dalam penelitian ini disesuaikan dengan materi pelajaran pendidikan agama Islam dan budi pekerti di kelas X SMKS-PP Putra Jaya Jabal Rahmah. Langkah-langkah yang dilakukan guru selama penerapan model pembelajaran leaning by doing akan dilakukan observasi sesuai lembar observasi guru dalam mengelola pembelajaran. Hal ini dilakukan untuk mengetahui sejauh mana tingkat keberhasilan pelaksanaan pembelajaran tersebut serta sebagai bahan evaluasi bagi peneliti di masa sekarang dan peneliti di masa mendatang. Berdasarkan pengamatan tentang kemampuan guru mengelola pembelajaran yang dilakukan dalam empat kali pertemuan dan satu kali pertemuan untuk melaksanakan tes kemampuan penalaran siswa diketahui bahwa kemampuan guru mengelola pembelajaran semakin meningkat. 
Journal Economy And Currency Study (JECS)

Volume 1, Issue 2, Juli 2019

Page 44-55

Adapun penghitungan statistik deskriptif lembar observasi model pembelajaran Learning by doing pada kelas eksperimen dan kelas kontrol dapat dilihat pada tabel 1 berikut:

\section{Tabel 1 Sebaran Data Nilai lembar Observasi \\ Model Pembelajaran learning by doing}

\begin{tabular}{cccccc}
\hline Kelompok & Mean & Median & Modus & Varians & Standar Deviasi \\
\hline Eksperimen & 34,029 & 17,25 & 35 & 490,138 & 22,139 \\
Kontrol & 33,88 & 17,75 & 34 & 9,57 & 18,04 \\
\hline
\end{tabular}

Sumber: Hasil Perhitungan Data Dengan Menggunakan aplikasi IBM SPSS Seri 20

Berdasarkan tabel 1 terlihat bahwa sebaran data nilai angket lembar observasi pengelolaan pembelajaran melalui model pembelajaran learning by doing pada kelas eksperimen adalah rataan hitungan (Mean) sebesar 34,029, median sebesar 17,25, modus sebesar 35, varians sebesar 490,138, dan simpangan baku (standar deviasi) sebesar 22,139. Sedangkan pada kelas kontrol rataan hitungan (mean) sebesar 33,88, median sebesar 17,75, modus sebesar 34, varians 9,57 dan simpangan baku (standar deviasi) sebesar 18,04.

\section{Kemampuan Penalaran Siswa}

Kemampuan penalaran siswa sebagai variabel terikat dalam penelitian ini diperoleh berdasarkan nilai tes kemampuan penalaran yang diberikan berupa soal uraian terkait materi pelajaran pendidikan agama Islam dan budi pekerti di kelas X SMKS-PP Putra Jaya Jabal Rahmah.

Adapun penghitungan statistik deskriptif pada sebaran data tes kemampuan nalar siswa pada kelas eksperimen dan kelas kontrol dapat dilihat pada tabel 2 berikut :

Tabel 2 Sebaran Data Nilai Tes Kemampuan Penalaran Siswa

\begin{tabular}{cccccc}
\hline Kelas & Mean & Median & Modus & Varians & Standar Deviasi \\
\hline Eksperimen & 905,29 & 17,25 & 80 & 193015,06 & 493,33 \\
Kontrol & 895,71 & 17,75 & 75 & 205297,26 & 453,09 \\
\hline
\end{tabular}

Sumber: Hasil Perhitungan Data Dengan Menggunakan aplikasi IBM SPSS Seri 20

Berdasarkan tabel 2 Diketahui bahwa sebaran data nilai tes kemampuan penalaran siswa pada kelas eksperimen diperoleh bahwa rataan hitungan (Mean) sebesar 905,29, median sebesar 17,25, modus sebesar 80, varians 193015,06, dan simpangan baku (standar deviasi) sebesar 493,33. Sedangkan pada kelas kontrol rataan hitungan (mean) sebesar 895,71, median sebesar 17,75, modus 
Journal Economy And Currency Study (JECS)

Volume 1, Issue 2, Juli 2019

Page 44-55

sebesar 75, varians 205297,26 dan simpangan baku (standar deviasi) sebesar 453,09 .

Sedangkan sebaran data indeks gain ternormalisasi (N-Gain) kedua kelas sampel tersebut dapat dilihat pada tabel 3 berikut:

Tabel 3. Data Indeks Gain Ternormalisasi Tes Kemampuan Penalaran Siswa Kelas Eksperimen dan Kelas Kontrol

\begin{tabular}{cccccc}
\hline Kelas & Mean & Median & Modus & Varians & $\begin{array}{c}\text { Standar } \\
\text { Deviasi }\end{array}$ \\
\hline Eksperimen & 6,53 & 17,25 & 0,6 & 18,78 & 4,33 \\
Kontrol & 8,84 & 17,75 & 0,33 & 22,13 & 4,70 \\
\hline
\end{tabular}

Berdasarkan tabel 3 diketahui bahwa sebaran data nilai tes kemampuan penalaran siswa pada kelas eksperimen diperoleh bahwa rataan hitungan (mean) sebesar 6,53 , median sebesar 17,25 , modus sebesar 0,6 , varians 18,78 , dan simpangan baku (standar deviasi) sebesar 4,33 Sedangkan pada kelas kontrol rataan hitungan (mean) sebesar 8,84, median sebesar 17,75, modus sebesar 0,33, varians 22,13 dan simpangan baku (standar deviasi) sebesar 4,70.

Sehingga, berdasarkan tabel 2 dan tabel 3 di atas dapat dijelaskan secara deskriptif bahwa (1) terdapat peningkatan kemampuan penalaran siswa setelah dilakukan pembelajaran Learning by doing pada kelas eksperimen, rerata peningkatan kemampuan penalaran siswa sebesar 0,39 dan berada pada kategori sedang; dan (2) rata-rata indeks gain ternormalisasi kemampuan penalaran siswa melalui pembelajaran Learning by doing terlihat lebih tinggi dibandingkan dengan rata-rata indeks gain ternormalisasi kemapuan penalaran siswa melalui pembelajaran biasa.

Peningkatan kemampuan penalaran siswa dapat diketahui berdasarkan jawaban hasil tes dalam bentuk uraian yang diberikan kepada siswa di akhir kegiatan pembelajaran (posttest). Berdasarkan jawaban tes tersebut dapat dideskripsikan bahwa kemampuan penalaran siswa secara kualitatif sebagai berikut :

1) Kemampuan mengaitkan materi pembelajaran dengan kehidupan nyata

Berdasarkan analisis tes kemampuan penalaran siswa kelas X SMKS-PP Putra Jaya Jabal Rahmah yang terdiri dari empat item pertanyaan dapat disimpulkan bahwa siswa kelas X SMKS-PP Putra Jaya Jabal Rahmah sudah mampu mengaitkan permasalahan yang diberikan oleh guru dengan kehidupan nyata baik dari pribadinya maupun dari lingkungan disekitarnya. 
2) Kemampuan menerapkan dan menyampaikan materi yang telah diterima kepada sesama

Berdasarkan hasil tes kemampuan penalaran siswa kelas X SMKS-PP Putra Jaya Jabal Rahmah rata-rata siswa sudah dapat menuliskan pengalaman mereka tentang menerapkan pengetahuan yang mereka dapatkan dari berbagai sumber, bahkan sebagian sudah pernah berbagi pengetahuannya tersebut kepada sesama. Oleh karena itu, pengetahuan yang mereka dapatkan akan lebih kuat melekat dalam benak dan fikiran mereka karena sudah mereka alami secara langsung dalam kehidupan nyata siswa.

Sehingga dapat diketahui bahwa kemampuan penalaran siswa terus mengalami peningkatan yang berarti dari waktu ke waktu. Hal tersebut juga dipaparkan secara kuantitatif berdarkan kategori tes kemampuan penalaran siswa yang dihitung menggunakan rumus sebagai berikut:

a. X $>($ Mean $+1,5$ Standard Deviasi $)$; kategori "Sangat Baik"

b. Mean $<X>($ Mean $+1,5$ Standard Deviasi) ; kategori "Baik"

c. (Mean + 1,5 Standard Deviasi) $<$ X $<$ Mean; kategori "Kurang Baik"

d. $X<($ Mean $+1,5$ Standard Deviasi $)$; kategori "Tidak Baik"

Berdasarkan data tes kemampuan penalaran siswa pada kelas eksperimen diperoleh bahwa rataan hitung (mean) sebesar 905,29, median sebesar 17,25, modus sebesar 80, varians 193015,06, dan simpangan baku (standar deviasi) sebesar 493,33. Sedangkan pada kelas kontrol rataan hitungan (mean) sebesar 895,71 , median sebesar 17,75, modus sebesar 75, varians 205297,26 dan simpangan baku (standar deviasi) sebesar 453,09.

\section{Pengaruh Model Pembelajaran Learning by Doing terhadap Kemampuan Penalaran Siswa}

Berdasarkan hasil penelitian yang telah dilakukan mengenai model pembelajaran leaning by doing dan kemampuan penalaran siswa dalam pelajaran pendidikan agama Islam dan budi pekerti mengindikasikan bahwa terdapat pengaruh model pembelajaran learning by doing terhadap kemampuan penalaran siswa. Hal tersebut diperoleh melalui analisis inferensial yaitu regresi linier sederhana. Sebelum melakukan analisis maka terlebih dahulu harus dipastikan bahwa sampel yang digunakan adalah sampel Random, sampel berdistribusi normal dan variasi sampel yang normal (Nazir, 2005 : 458). Tujuan dari analisis regresi yang dilakukan pada penelitian ini adalah untuk menguji apakah korelasi antara dua variabel tersebut signifikan atau tidak.

Selain untuk menguji signifikansi korelasi uji regresi juga bertujuan untuk mencari pengaruh antara kriterium dan prediktor, serta untuk menguji seberapa besar variasi variabel dependen dapat diterangkan oleh variasi variabel independen (Nazir, 2005:458). 
Data yang diperoleh pada sampel penelitian terkait variabel bebas (pembelajaran learning by doing) dan variabel terikat (kemampuan bernalar) telah dibentuk menurut pola statistik inferensial dan dihitung dengan

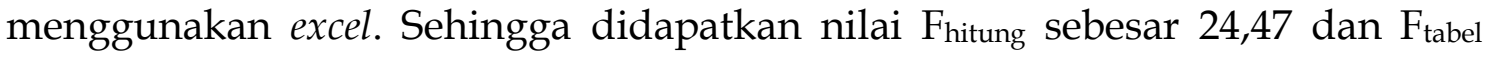
$(1,28)(0,01)$ sebesar 7.56. Hal ini menunjukkan bahwa nilai $F_{\text {hitung }} \geq F_{\text {tabel, yang }}$ berarti $\mathrm{H}_{\mathrm{a}}$ diterima dengan hasil terdapat pengaruh yang signifikan antara pembelajaran Learning by doing terhadap kemampuan penalaran siswa pada mata pelajaran Pendidikan Agama Islam dan Budi Pekerti bagi siswa kelas X SMKS-PP Putra Jaya Jabal Rahmah Stabat. Dengan kata lain, siswa yang mendapatkan pembelajaran melalui model pembelajaran learning by doing akan berpengaruh terhadap kemampuan penalaran siswa tersebut.

Sedemekian sehingga pada saat pembelajaran melalui model pembelajaran Learning by doing maka akan meningkatkan kemampuan penalaran siswa. Sehingga siswa dapat meningkatkan hasil belajarnya pada mata pelajaran Pendidikan Agama Islam disebabkan kemampuan penalaran siswa dapat dikembangkan dengan baik.

\section{KESIMPULAN}

Berdasarkan pembahasan dan hasil penelitian yang telah dipaparkan sebelumnya, maka dapat disimpulkan berkaitan dengan pengaruh model pembelajaran learning by doing terhadap kemampuan penalaran siswa bahwa: (1) terdapat peningkatan kemampuan penalaran siswa yang diajar melalui model pembelajaran learning by doing bagi siswa kelas X SMKS-PP Putra Jaya Jabal Rahmah yang memiliki hasil rataan (mean) sebesar 34,029, median sebesar 17,25, modus sebesar 35, varians 490,138, dan simpangan baku (standar deviasi) sebesar 22,139. Sedangkan pada kelas kontrol rataan hitungan (mean) sebesar 33,88, median sebesar 17,75, modus sebesar 34, varians 9,57 dan simpangan baku (standar deviasi) sebesar 18,04 dapat diterima dengan batas signifikasi toleransi; dan (2) terdapat pengaruh yang signifikan antara model pembelajaran learning by doing terhadap kemampuan penalaran siswa dalam mata pelajaran Pendidikan Agama Islam bagi siswa kelas X SMKS-PP Putra Jaya Jabal Rahmah

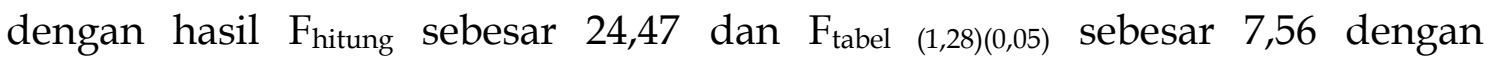
persamaan garis regresi sebesar $\mathrm{Y}=38,89+1,17 \mathrm{X}$.

Lebih lanjut, semoga penelitian yang telah dilakukan dapat menjadi rujukan untuk peneliti selanjutnya dengan menggunakan berbagai pendekatan atau model pembelajaran lainnya yang lebih menarik perhatian, minat, bahkan sikap siswa dalam melakukan pembelajaran di kelas. 
Journal Economy And Currency Study (JECS)

Volume 1, Issue 2, Juli 2019

Page 44-55

\section{REFERENCES}

Alamsyah. (2000). Pembelajaran untuk Meningkatkan Kemampuan Penalaran Analogi Matematika. Jurnal Penelitian dan Pembelajaran Matematika, 8 (1), 27-30.

Arcat \& Lusi Eka Afri. (2017). Kemampuan Penalaran Siswa Kelas VII SMP Kecamatan Tambusai Tahun 2017. Edu Research: Jurnal Ilmiah, 6 (2), 34-42.

Istarani. (2014). 58 Model Pembelajaran Inovatif. Medan: Media Persada.

KBBI.web.id(online) diakses pada 05 November 2016 pukul 12.45.

Kusmanto, Aris, dkk. (2014). Pendekatan Learning by Doing dalam Pembelajaran

Fisika dengan Media Riil dan Multimedia Interaktif Ditinjau dari Kreativitas dan Motivasi Berprestasi. Jurnal Inkuiri, 3 (3), 65 - 74.

Nazir, Moh. (2005). Metode Penelitian. Jakarta: Ghalia Indonesia.

NCTM. (2000). Principles and Standards for School Mathematics. United States of America : The National Council of Teachers of Mathematics, Inc.

Uno, Hamzah B. (2007). Model Pembelajaran Menciptakan Proses Belajar Mengajar yang Kreatif dan Efektif. Jakarta: Bumi Aksara.

Uno, Hamzah B \& Nurdin Mohamad. (2011). Belajar dengan Pendekatan PAILKEM. Jakarta: Bumi Aksara. 